\title{
'Manxness': Uses of Heritage on the Isle of Man
}

\author{
ELIZABETH CATTE
}

$\mathrm{I}$

n her 2006 work Uses of Heritage, archaeologist Laurajane Smith argues that heritage is a social construction dominated by an 'authorized heritage discourse' in which experts and authorities 'forge a sense of common identity based on the past' from 'materially pleasing objects, sites, places, and / or landscapes'. 'This argument suggests that the construction of heritage is often a top-down process managed by governments in order to naturalize narratives and identities the state finds valuable. As a challenge to future researchers, Smith encourages additional work that explores 'the links between heritage and expressions of identity' as a way to shift heritage studies away from what heritage is to what heritage does. ${ }^{2}$ In this article, I analyze the construction of heritage - both as a discourse and an industry - in the Isle of Man, a small quasi-independent island in the middle of the Irish Sea with an ambitious model of heritage branding. Rather than focusing

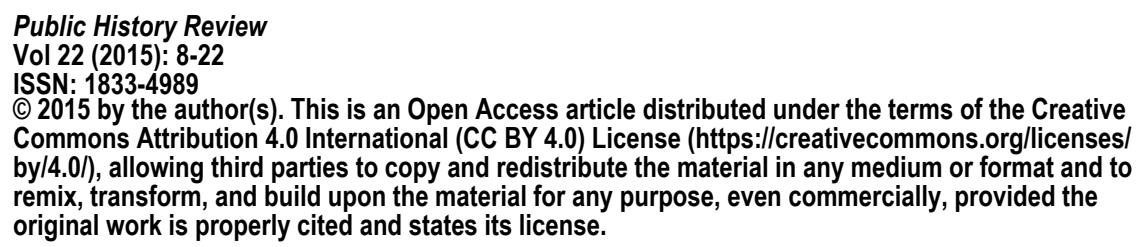


on what heritage is in the Isle of Man, I examine, as Smith suggests, what its heritage does. I argue that the Isle of Man deploys what it sees as a universally-accessible and consumable heritage brand as a way to create social stability among a diverse and rapidly changing population by offering opportunities to forge a shared identity through the celebration of its unique culture. By constructing a highly symbolic identity that is heavily dependent on its tangible and intangible heritage assets, the Isle of Man is an exemplar of what Smith calls the 'vital and representative role' of heritage in the creation of national identities. ${ }^{3}$

As Rodney Harrison notes, however, critical heritage studies that 'focus on the role of heritage in the production of state ideologies' often overlook that 'heritage is fundamentally an economic activity.'‘A central element of my argument is that the Isle of Man's dual and sometimes dueling cultural and economic priorities have produced widespread ambiguity as to what its national identity actually is. As a cultural and economic enterprise, the Isle of Man's heritage branding model emphasizes the Island's 'otherness' - its cultural distance from neighboring British countries - as a way to shore up the uniqueness of its heritage assets for the purposes of tourism. This 'otherness' implies that the Isle of Man is perpetually vulnerable to outside influences and the forces of globalization that threaten dilute or displace the very elements that make the island so different and inviting. Yet, the Isle of Man is globalized. Approximately thirty-four per cent the island's income approximately $£ 1.1$ billion annually - is generated by a finance sector heavily populated with foreign workers. ${ }^{5}$ Therefore, 'authorized heritage discourse' on the Isle of Man is rife with tensions that arise between the competing demands of multiculturalism and nationalism in an environment that seeks to balance its sense of past alongside a globalizing economy. How the Isle of Man uses heritage to create what Ien Ang calls the 'symbolic glue of unifying cultural nationalism' is a complicated but fascinating process and requires us to examine how the Island's definitions of heritage change over time. ${ }^{\circ}$

I conclude by sharing my experiences as a foreign heritage worker on the Isle of Man. I moved from the United States to the Isle of Man in 2007 at a time when the Isle of Man government took an unprecedented interest in its international identity. That year, Britain experienced 'one of the biggest waves of immigration' in recent history as a result of the accession of ten new countries to the European Union in 2004. 'Although immigration to the Island was more limited, the government issued hundreds of work permits to Eastern European migrants while the local papers announced that migrant workers were 'quite a large percentage 
of the Island's population.'s The same year, the Isle of Man introduced a citizenship test as an immigration requirement and, as a separate but related enterprise, formalized an agreement that clarified the Island's Constitutional relationship with the United Kingdom. As an outsider and particularly as a heritage worker, I observed a range of actors - from politicians to academics to ordinary members of the public - express contradicting opinions as to what values the Island represented and what image it should project in the wider world.

\section{THE ISLE OF MAN AND 'MANXNESS'}

The Isle of Man is a self-governing British Crown dependency located in the center of the British Isles in the Irish Sea. Its total area is just 221 square miles - thirteen miles wide by thirty-nine miles long. As of its last census in 2011, the Island's population was 84,497 and approximately forty-eight per cent were born on the Island. Called Ellan Vannin in the native Manx language, the Island has a historically Gaelic-Norse culture that reflects periods of settlement by both Briton Celts and Vikings. In the twenty-first century, the Isle of Man is perhaps best known for its annual Tourist Trophy (TT) races, which can draw as many as 40,000 visitors to the Island. ' With no corporation tax, inheritance tax, capital gains tax and capped income tax, the Isle of Man is viewed by many as a 'tax haven' and as such generates a substantial amount of revenue through international banking.

The changing economic profile from tourist destination to off-shore banking juggernaut in the 1980s resulted a shift in demographics that reflected an influx of migrants - called 'comeovers' in the local vernacular - from England, Scotland, Wales and Ireland. These social changes triggered a broad national concern for local autonomy and a parallel desire to protect the Island's sovereignty from undue outside influence. In this way, the Island's voluntary 'othering' of its traditions and history underscored its cultural if not territorial distance from the United Kingdom. While this 'othering' had the immediate effect of bolstering the Isle of Man's claim to a separate political identity, it also create the basis for a powerful model of heritage branding used to reinforce a national identity for the purposes of social stability..$^{10}$

In 2007, the Chief Minister of the Isle of Man and the United Kingdom's Secretary of State issued 'a framework for developing an international identity of the Isle of Man'. Amongst other points that clarified the Constitutional relationship between the two entities, the framework summarized a millennium of historical debate bluntly and briefly: going forward, it could forever be said that 'the Isle of Man has 
an international identity which is different than the UK'. While a desire to enshrine the unique qualities of Manx culture had been present on the Island since the late-Victorian era, this modern revival activity was distinctly political in nature, organized largely through the Department of Education and the Island's statutory heritage body Manx National Heritage. Through the introduction of a new national curriculum and heritage programming that placed Manx history, culture and language at the center of all educational initiatives, the government made ambitious plans to teach both students and adults what it meant to be authentically Manx.

So what, then, is Manx? It is a surprisingly difficult quality to define. For example, for all its posturing about the Isle of Man's international identity, the Island's government offers little guidance about specifically who or what is authentically Manx. Only in political documents that articulate the Island's relationship, or lack of, with the European Union does the Isle of Man come close to defining 'Manx' as a discrete category of persons. These documents make reference to 'Manxmen' as a category of persons born, adopted, naturalized or registered in the Isle of Man without close family ties to the United Kingdom or a period of continuous residency in the United Kingdom for a period of more than five years. These documents stipulate that 'Manxmen', although British for purposes of citizenship, have no right to benefit from the United Kingdom's membership in the European Union and must carry a stipulation of such in their passports and travel documents." By recent estimates, this category could be less than five per cent of the population and, by definition, would include certain categories of migrants coming from outside the European Union..$^{12}$ Informally, individuals on the Isle of Man refer to most persons born on the Island as 'Manx', although children born to parents from outside the British Isles occupy a somewhat ambiguous space in the Island's identity politics.

Beyond these narrow definitions, the Island's more common way of expressing its 'Manxness' as a shared culture is through the celebration of traditions that emphasize its uniqueness and cultural difference from the United Kingdom. Manx politician D.G. Kermode wrote that the 'essence' of the Isle of Man's separate identity can be found in Tynwald, the Isle of Man's legislative body which the Island claims as the world's oldest continuous parliament. ${ }^{13}$ Festivities during the annual Tynwald Day holiday celebrate the Island's ancient Viking and Celtic roots and heritage as well as its distinct political status. The Island's cultural differences are also expressed through the recent Manx language revival. In 2009, UNESCO declared Manx Gaelic - a written and spoken 
language similar to Irish and Scottish Gaelic - officially extinct, much to the frustration of Manx Gaelic speakers on the Island. As a symbolic public language, Manx Gaelic is used by the (now) bilingual government, through Manx Gaelic radio broadcasts and most significantly through the Island's language curriculum and dedicated Manx Gaelic schools such as the Bunscoill Ghaelgagh, which delivers primary instruction to students using only Manx Gaelic. Since more than half of the Island's population hails from elsewhere in the British Isles, embracing resurrected Manx customs and Manx Gaelic are important ways that newcomers proclaim that they are, at heart, Manx people..4

Individuals in the Isle of Man also proclaim their 'Manxness' - a state that historian Frank Kermode once described as 'mild alienation' and 'qualified foreignness' - through a range of other activities, from buying Manx products to christening their children with traditional Manx names. ${ }^{15}$ Sociologists who have studied the Isle of Man have noted the enthusiasm with which new residents attempt to embrace a shared identity and assimilate. ${ }^{16}$ Such studies stress the Island's opportunities for 'communal participation, irrespective of place of origin'. But it must be said that within this work there is little attention as to how 'Manxness' might or might not be embraced by individuals who are non-white or not ethnically similar to the Island's white British majority." ${ }^{17}$ Although I am white, I often sensed the limits of 'Manxness', especially during my employment with Manx National Heritage, which required me to learn token Manx Gaelic and perform living history re-enactments assuming the identity of a native born Manx individual. I found this exclusion to be somewhat ironic as, for the purposes of immigration, I was one of the five per cent of individuals defined as a 'Manxman' by the government due to my naturalization on the Island.

The use of 'Manx' as a quasi-ethnic identity requires further consideration. A poll conducted by the newspaper Isle of Man Courier in 2009 indicated that sixty-eight per cent of residents felt that racism was a problem on the Island, and a further forty-three per cent expressed sympathy toward 'racist views' ${ }^{\text {. }}$. As migration to the Island grew to include incomers not only from the British Isles, but also Eastern Europe, Africa and Asia, so did pushback that argued the 'real' targets of racism were 'indigenous' Manx individuals. ${ }^{19}$ Indeed, variations on this refrain that native Manx individuals are treated as a minority in their own land - are repeated in the heritage policy documents (discussed below). It is tempting to view this pushback and voluntary 'othering' of 'Manxness' as part of an ongoing cultural project in which the decline of a collective British identity is replaced by a preference for separate identities such as English, Scottish or Welsh. However, the Manx claim to a separate 
cultural identity has much different historical and political dimensions due to the Island's distinct Constitutional status, declining island-born population and dependence on the tourist industry. As we will see, these claims take root during the Victorian era as individuals associated with Manx arts refashioned the Island's Celtic identity during the peak of English tourism on the Island.

\section{THE CONSTRUCTION OF A PEOPLE's HISTORY}

It is possible to trace to the Isle of Man's preoccupation with 'Manxness' to a broad Celtic revival that occurred in the British Isles in the mid1800s, although historian John Belchem notes that Celticism appeared later in the Isle of Man due to an absence of antiquarian societies on the Island. ${ }^{20}$ These groups, once they began to flourish, did so with an intense ambition to create and protect a national spirit that was distinctly nonEnglish and would exist in contrast to the 'imperial pride' in the 'racial discourse of late Victorian British politics. ${ }^{2}$ Archaeologist Catriona Mackie argues that the Island's separate political identity allowed Manx antiquarians and revivalist to focus on the development of a separate cultural identity based on Celticism through 'the study of archaeology, language, and folklore. ${ }^{22}$ In essence, Manx revivalists in the pursuit of Celticism used intangible elements of culture to create cultural capital for themselves in a process that Rodney Harrison calls heritage as a social action. ${ }^{3 s}$

The rise of Celticism in the Isle of Man also coincided with the development and investment in the Island's tourism industry, which brought frequent visitors from the North of England to the place. By the turn of the century, tourism replaced traditional industries such as fishing and mining as the Island's dominant enterprise. The Island's economic dependence on tourism generated a broad interest in the unique qualities of the Isle of Man, both as a means to shore up is nascent tourism industry and enshrine the cultural difference of the Manx people from their English visitors. According to Belcham, Celticism achieved both ends by offering Manx individuals a way to strengthen their cultural capital through 'indigenous cultural productions. ${ }^{2}$ At the first Pan-Celtic Congress held in Dublin in 1901, it was proudly proclaimed that 'The Isle of Man was at the centre of the Celtic peoples... Though mountains and wastes of seas divided, yet still the blood remained. ${ }^{25}$

The birth of Celticism in the Isle of Man can be traced to a small cohort of English-educated Manx artists and writers who wished, Belchem notes, to position 'an essential Celtic racialism' as the key aspect 
of a new national spirit. ${ }^{26}$ This cohort - which included Manx artist T.E. Brown, antiquarian A.W. Moore and folklorist Sophia Morrison - often fused history with myth to bolster their belief in cultural separatism, resurrecting, for example, the Irish sea god Manannan Mac Lir as a composite stand-in for the Island's ancient rulers. This resurrection of cultural symbols continued with the Manx coat of arms: a triskelion (or ny tree cassyn in Manx) above a Latin motto Quoqunquejerecisstabit (where so ever you throw it, it will stand).27 These scholars also helped preserve Manx Gaelic, already dying out, but faced difficulties learning the language themselves and eventually resigned it to scientific study without elevating it to the level of national passion seen in the twentyfirst century. While much of the work of antiquarians was intended to be consumed by other well-educated and curious scholars, a growing number of Manx revivalists believed that their efforts should be directed at the general public as well. Sophia Morrison, in particular, is still best known on the Island for her collection of fairy lore, which had great popular appeal.

Although Manx Celticism lacked the political bite found in Irish Celticism, there were moments when the Isle of Man's national revival had political implications. For example, the folklore publication Mannin occasionally received correspondence from 'rabid' sectarians who favored complete legislative annexation from the United Kingdom..$^{23}$ This strife made the leaders of Manx cultural revival anxious, as they believed that one of the chief hallmarks of the Isle of Man's national spirit was the absence of the 'internal schism' characteristic of other Celtic nations and especially, at this time, Ireland..$^{20}$ The specter of World War I also raised political questions regarding the limits of the Isle of Man's independence, but such conversations never rose above intellectual challenges. Indeed, modern Manx revivalist Breesha Maddrell has argued that Manx Celticism 'promoted, consciously or not, a duality of identity, of Manxness and Britishness. ${ }^{\prime 30}$

While sometimes impatient with those who questioned their credentials as an ethnic minority, the people of the Isle of Man nevertheless remained, in the opinion of Belchem, pragmatic in their nationalist politics: 'As a political program, Manx nationalism has always sought to exploit offshore independence to attract 'strangerresidents' vital for the Island's economic well-being'. The most recent of these 'stranger-residents' were off-shore banking executives and tax exiles.". The development of Manx cultural identity at the turn of the century reflects these tensions between economic dependence and cultural independence. While revivalists created and re-created cultural products as a form of resistance to the influence of English holiday 
makers, those in the tourist industry packaged this new distinct Manx culture as an attractive feature to visitors.

Although the development of a Manx identity takes place in a different historical and political context than the rise of Englishness or Scottishness as a cultural process, what is true and shared is that the Isle of Man relies on heritage assets to communicate what this identity is and who can claim it. In the 1980s, the rise of statutory heritage bodies in the United Kingdom such as English Heritage brought with their development a new era that privileged cohesion with the past as a source of social stability. This also describes the transformation of a statutory heritage body on the Isle of Man, although its most active period was the 1990s which saw an intensification of globalisation. Returning to Smith's argument, what is particularly striking about the rise of authorized heritage on the Isle of Man from the 1990s to present is the creation of a boundary between 'those who have the ability or authority to "speak" about or "for" heritage... and those who do not. ${ }^{\prime 2}$ In the Victorian era, the development of a Manx cultural identity became a collaborative enterprise in which individuals together explored what it might or might not mean to be Manx. In the twenty-first century, however, most definitions of national identity must flow through the government using Manx National Heritage as its proxy.

\section{THE MODERN HERITAGE INDUSTRY ON THE ISLE OF MAN}

The Isle of Man government created Manx Museum and National Trust in 1951 as its statutory heritage body and its oversight is provided by a traditional Board of Trustees. In 1991, this entity transformed into Manx National Heritage. Catriona Mackie argues this transformation 'reflected a shift in the operational policy of the organization, which has become more firmly centered on improving community involvement, more actively engaging with the tourist market, and continuing the promotion of a positive national and international identity for the Island.' ${ }^{\prime x}$ Manx National Heritage is headquartered in the Manx Museum in Douglas, which opened in 1922, and it manages twelve other primary heritage sites and further operates a National Museum Service, a National Monuments Service, a National Trust, a National Library and Archive and a National Art Gallery. The mission of Manx National Heritage is, in part, to 'lead the Island's community in recognising, understanding, valuing and promoting its cultural heritage and identity to a world-wide audience' in order to 'strengthen the Manx identity and community by giving opportunities for enjoyment, learning and development.' Manx National Heritage receives an approximately $£ 4 \mathrm{~m}$ budget from the Isle of 
Man government and serves roughly a quarter million visitors per year at its combined heritage sites. Narrative cohesion at the organization's diverse sites - which range from animatronic-heavy museums to ancient monuments - was maintained for many years through 'The Story of Mann', a slick presentation of the Island's history designed for easy visitor consumption. 'The international prestige and image of the island will be considerably increased in the future by a continuation of the quality controlled presentation of the Island's unique cultural and natural assets', stated the Isle of Man government in 1999. ${ }^{34}$

Just five privately-run heritage sites exist on the Island: the Manx Transportation Museum, the Leece Museum, the Manx Aviation Museum, the Milntown Estate and the Jurby Transportation Museum. As a result, responsibility for the Island's cultural branding rests largely in the hands of the government and its organ, Manx National Heritage. The influence of Manx National Heritage can be seen in its attitude toward a unified heritage strategy concept. In 2002, for example, the former Director of Manx National Heritage, Stephen Harrison, asserted that his organization held 'largest museum identity in the British Isles' by claiming all 227 square miles of Island as interpreted space through 'The Story of Mann.' ${ }^{3 s}$ The expansive remit was justified, Harrison commented, by the fact that 'the changing nature of the social structure the new financial markets bringing new families to live in the island with no background knowledge of its life and traditions, is resulting in a situation... where the native-born Manx people are now an ethnic minority in the own land. ${ }^{\text {ss }}$ Under Harrison's directorship, Manx culture largely became the intellectual property of the government to be conserved and protected against outside influence.

With few exceptions, Manx National Heritage presents an idealised image of Manx life that promotes political and cultural unity, industriousness and the achievements of legendary figures. Tony Gilmour observed similar values at work during the growth of the English heritage industry in the 1980s. ${ }^{.7}$ Critics such as Robert Hewison and David Lowenthal have argued that an obsession with these values is indicative of a distinctly conservative view of the past that risks exploiting heritage for commercial and political gain. ${ }^{38}$ Smith and Rodney Harrison, however, have emphasized in their work the ways that local culture, history and heritage 'competes' with official, national discourse to destabilize what Harrison calls the 'cannon' of authorized heritage sites and practices..$^{39}$ The potential of such competition in the Isle of Man is complicated by the lack of 'unauthorized' heritage sites and bodies. Heritage attractions and organizations that exist independently of the 
government occupy a niche market that is not supported by the same robust financial backing that national heritage sites enjoy.

A number of examples illustrate the tensions embedded in the Isle of Man's 'authorized heritage discourse.' Since the late 1930s, the Isle of Man government has owned and maintained structures - cottages and agricultural buildings and their associated lands - in the village of Cregneash as an open-air museum that interprets elements of traditional Manx farming and rural life. Interpretation is provided through an interpretive center opened in 1984 and by costumed heritage workers that interact with visitors and demonstrate period crafts and farming techniques. The setting is intended to provide visitors with a glimpse into the 'unspoiled' and 'traditional' character of an authentic Manx village. ${ }^{\text {to }}$ As such, Manx National Heritage maintains considerable interest in the village at large and routinely acquires additional property as it becomes available while leasing uninterpreted cottages to local residents. Many residents of Cregneash feel that Manx National Heritage has trapped their village in the past for the benefit of its museum by using its government influence to prevent homeowners and tenants from modernizing their structures.

In 2007, Manx National Heritage won a 'landmark' case against a homeowner in Cregneash to prevent the construction of a modern property addition that the organization felt 'threatened the integrity of a national folk museum.' "A year later, a flower show in the village highlighted residents' frustration with Manx National Heritage when residents transformed the set theme 'Hope Springs Eternal' into 'Hope for Planning Permission' and constructed floral exhibits that featured miniature dilapidated Manx cottages. The outsized influence of Manx National Heritage became an issue in Cregneash once again in 2014 when the community met to discuss renovation plans for St Peters Church, one of the most recognizable and visited yet privately owned structures in the village. Several residents left the meeting with the impression that Manx National Heritage would attempt to block renovation attempts unless the congregation allowed the organization to use the church for its own secular events. One resident who was born in Cregneash commented, 'MNH has destroyed a living village... just walk around and look what they have done to it.' ${ }^{\prime 2}$

Although Manx National Heritage has insisted that it exists at the pleasure of the 'community's terms' at times the community's desires to celebrate its heritage have been out of sync with branding priorities." $\mathrm{In}$ 2010, Manx National Heritage, labelled as the guardians of the Isle of Man's culture' in the press, angered locals when it issued a statement 
that the much beloved Manx attraction Fairy Bridge was not culturally significant." In rejecting an application to create an official heritage attraction at Fairy Bridge - a site significant in local folklore - the organization stated 'Manx National Heritage have a duty to protect the Island's heritage, and their expert view is that this bridge is not an important part of the heritage. ${ }^{\prime 45}$ While their rejection continued to list a number of practical considerations including potential disruption of traffic and public access, the tone of the organization's pronouncement frustrated some. Although the bridge is one of the more whimsical elements of Manx culture, it nevertheless serves as an important cornerstone of what many on the Island find endearing about the Isle of Man and it is a frequent stop for tourists. As one commenter lamented, 'No matter whether Manx National Heritage believe it or not, the Fairy Bridge is as much a part of island life as the government itself. ${ }^{\prime}{ }^{6}$

The above examples indicate that the 'quality controlled presentation' of the Island's heritage elevates certain aspects of 'Island life' while omitting others. The interpreted experience of the Isle of Man during World War II is also representative of this process. To underscore the Island's uniqueness, Manx National Heritage uses a narrative of enemy alien internment to position the Island's cultural difference from the United Kingdom. Although the Isle of Man sent, per capita, more men to serve in the British Army than anywhere else in the British Isles, the dominant story of World War II on the Isle of Man is that of internment." During World War II and through orders from the Westminster government, the Isle of Man interred approximately 14,000 'enemy aliens' at ten internment sites. Unlike controversy in the United States related to the historic legacy and subsequent interpretation of Japanese-American internment during World War II, the Isle of Man and Manx National Heritage are not hesitant about laying claim to a perhaps shameful and inglorious past.

In Manx's Natural Heritage's primary social history museum, the Manx Museum, the beginning of World War II is conveyed through the presentation of the bedroom of a seaside holiday resort. A dividing line cuts across the bedroom, representing the threshold between war and peace. The last moments of peace are conveyed through the display of a suitcase, cheery bedding and a collection of trinkets, while war comes as the same room is shown sparsely decorated with striped pajamas resting near the bed to signal internment. Manx National Heritage interprets the experience of internment as largely suffered by enemy aliens and the Manx alike - a dual humiliation thrust upon them by a foreign government that both groups endured as best they could. 
The answer to why this is so and how these choices came to be to be lies on the long history of Manx 'otherness' combined with the more recent focus on neatly presented and consumable heritage. Historians Daniel Travers and Stephen Heathorn have argued that in privileging the narrative of internment, Manx National Heritage has 'on a whole... marginalized the military heritage of the Manx' in order to tell a story that cannot be duplicated in the United Kingdom. ${ }^{48}$ Thus the collective memory of World War II on the Isle of Man is not that of Britain and a victorious 'People's War' but a morally ambiguous episodic event that nevertheless conforms to Island's branding as culturally unique and somewhat long suffering of British whims. This is not to say that the decision to use internment as the dominant interpretive theme is inappropriate. Manx National Heritage, particularly in its function as the National Library and Archives, possesses unparalleled collections relating to internment, including material culture, works of art, and full complement of archival resources unavailable in the United Kingdom. To commemorate the centennial of the Great War in 2014, Manx National Heritage has produced a temporary exhibit This Terrible Ordeal and corresponding published letters collection, as well as sponsoring an international conference on internment during World War I..$^{4^{9}}$

Smith argues that 'heritage and the identities and of both the past and the present it creates do not simply exist internally to the group or other collective that has created them - they do work, or have a consequences, in wider social, cultural, economic and political networks. ${ }^{{ }^{s} \mathrm{I}}$ In the examples and discussion above, I hope that I have given readers an understanding of what heritage is and does on the Isle of Man. However, I can offer no clearer evidence of how heritage and identity politics function together and do the work that Smith describes than to offer my own reflections of my time as a foreign heritage worker on the Isle of Man.

\section{ARE WE MANX YET?}

In 2007 and already a resident of the Isle of Man, I accepted a position within the Education Department of Manx National Heritage. Although the Education Department managed adult education and community outreach as well, its primary function at the time was to facilitate a partnership with the Island's Department of Education to deliver Manx curriculum-based workshops at the organisation's heritage sites. These hands-on lessons exposed children not only to Manx history, but also Manx geography, language, arts and natural conservation. In other words, it was my job to assist young learners to grasp what it meant to 
be Manx and to promote the Isle of Man's cultural vision through its heritage assets. In more ways than I was prepared to admit at the time, this became a mutual learning experience.

Garth Stevenson writes that 'the disadvantage of cultural nationalism is that it arouses little or no interest on the part of minorities that may be present on the territories, and who do not share the culture in question. In fact, it might even repel them. 'si To a large extent, Manx National Heritage is content to tell individuals what it means to be Manx, rather than create the space for conversations in which aspects of 'Manxness' may be teased out, explored and questioned. Although the Isle of Man government and Manx National Heritage consider much of this reinforcement to be in the service of promoting inclusion, I found that these accumulated messages made it more difficult for me to relate to individuals as immigrants. Because the Island is so proudly 'othered' there is little room to tell the stories of individuals who grappled with a sense of belonging. It is generally true on the Isle of Man that the Island becomes more 'Manx' during periods of heavy immigration and migration, and therefore we assume that 'Manxness' could never be obtainable to us because it is designed to serve as a foil to us.

'Manxness' also functioned as a class status in ways that made my exclusion feel sharper. As Smith argues, 'Within the narrative of nation, heritage discourse also explicitly promotes the experience and values of elite social classes. 's She further explains that heritage discourse recreates class 'by privileging the expert and their values over that of the nonexpert, and by the self-referential nature of the discourse, which continually legitimizes itself and the values and ideologies on which it is based.'ss This is particularly true of the Isle of Man. As in Ireland, for example, most speakers of Gaelic - which in the Isle of Man is a wellregarded form of 'Manxness' - are from an educated and middle-class cohort.st The audience for the Island's heritage programing is largely educated and middle-class as well. Although the Isle of Man government and Manx National Heritage does aspects of community outreach extremely well - a robust variety of low or no-cost programs is always on offer - there is room for the organization to stretch the definition of its community.

As a historian, I spent an inordinate amount of time thinking about how other non-British migrants and / or working-class individuals experienced the Island and navigated its complicated identity politics. It was disappointing that my most enduring answers to those questions came not through my time working for the Island's heritage body but through my brief employment in the financial sector before I returned to the United States. There, I encountered migrant workers raising dual- 
identity children while struggling with the same exclusion I felt upon arrival along with native-born individuals who maintained a much more flexible and less hegemonic sense of identity. In the more globalized world of the financial sector, the ambiguities of 'Manxness' at last revealed themselves to be something that we could all share.

\section{ENDNOTES}

${ }^{1}$ Laurajane Smith, Uses of History, Routledge, New York, 2006, p11.

2 ibid, p308.

3 ibid, p48.

${ }^{4}$ Rodney Harrison, 'What is Heritage?', in Rodney Harrison (ed), Understanding the Politics of Heritage, University of Manchester Press, Manchester, 2009, p14; italics in original.

${ }^{5}$ Ernest \& Young, 'Isle of Man: Economic Research Report', May 2012. Accessed 28 September 2015. Accessed via: $<$ http://goo.gl/zmmkul>.

${ }^{6}$ Ien Ang, 'Between Nationalism and Transnationalism: Multiculturalism in a Globalising World', Institute for Culture and Society Occasional Paper Series, vol 1, no 1, 2010, p5.

7 'Wave of Polish Immigration Over Says Ambassador', Independent, 21 April 2014. Accessed 16 May 2015. Accessed via: <http://goo.gl/1vo6Ya>.

8 'Island Welcomes Polish Workers', Isle of Man Today, 10 October 2007. Accessed 16 May 2015. Accessed via: <http://goo.gl/9Zq4Xy>.

${ }^{9}$ See Isle of Man TT website. Accessed 16 May 2015. Accessed via: <http://www.iomtt.com/>.

${ }^{10}$ Stephen Harrison, 'Culture, Tourism and Local Community - the Heritage Identity of the Isle of Man,' Brand Management, vol 9, no 4-5, 2002, p359.

${ }^{11}$ Fiona Murray, The European Union and Member State Territories: A New Legal Framework Under the EU Treaties, T.M.C. Asser Press, The Hague, Amsterdam, 2012, p158.

${ }^{12}$ Cheryl Cheek, Sue Nicol and Sarah Grainger, 'Manx Identity and the Comeovers', in Jodie Matthews and Daniel Travers (eds), Islands and Britishness: A Global Perspective, Cambridge Scholars Publishing, Newcastle upon Tyne, 2012, p70.

${ }^{13}$ D.G. Kermode, Offshore Island Politics: The Constitutional and Political Development of the Isle of Man in the Twentieth Century, Liverpool University Press, Liverpool, 2001, p4.

${ }^{14}$ Diarmuid O'Néill, Rebuilding the Celtic Languages: Reversing Language Shift in Celtic Countries, Y Lofta, Wales, 2002, p415.

${ }^{15}$ Quoted in John Belchem, 'The Little Manx Nation: Antiquarianism, Ethnic Identity, and Home Rule Politics in the Isle of Man, 1880-1918', Journal of British Studies, vol 39, no 2, 2000, p218.

${ }^{16}$ Cheek et al, p75.

17 ibid.

18 'Racism: A dirty little Manx secret', Isle of Man Today, 21 December 2009. Accessed 16 May 2015. Accessed via: < http://goo.gl/zKytLM>.

19 ibid.

${ }^{20}$ Belchem, op cit, p218.

${ }^{21}$ ibid, p217.

${ }^{22}$ Catriona Mackie, 'Open-Air Museums, Authenticity and the Shaping of a Cultural Identity: An Example from the Isle of Man', in Chris Dalglish (ed), Archaeology, the Public and the Recent Past, Boydell and Brewer, Suffolk, 2013, p17.

${ }^{23}$ R. Harrison, op cit, p38.

${ }^{24}$ Belcham, op cit, p220.

${ }^{25}$ Quoted in Belchem, p220.

${ }^{26}$ ibid, p221.

${ }^{27}$ Queen Elizabeth II recognized the Isle of Man's coat of arms as 'the arms of her Majesty in right of the Isle of Man' in 1996, although Manx dignitaries have used the coat of arms - believed to date from the $13^{\text {th }}$ century - since 1872 .

${ }^{28}$ Breesha Maddrell, 'Speaking from the Shadows: Sophia Morrison and the Manx Cultural Revival', Folklore, vol 113, no 2, 2002, p230.

${ }^{29}$ ibid, p233.

30 ibid.

${ }^{31}$ Belchem, op cit, p240.

${ }^{32}$ Smith, op cit, p12. 


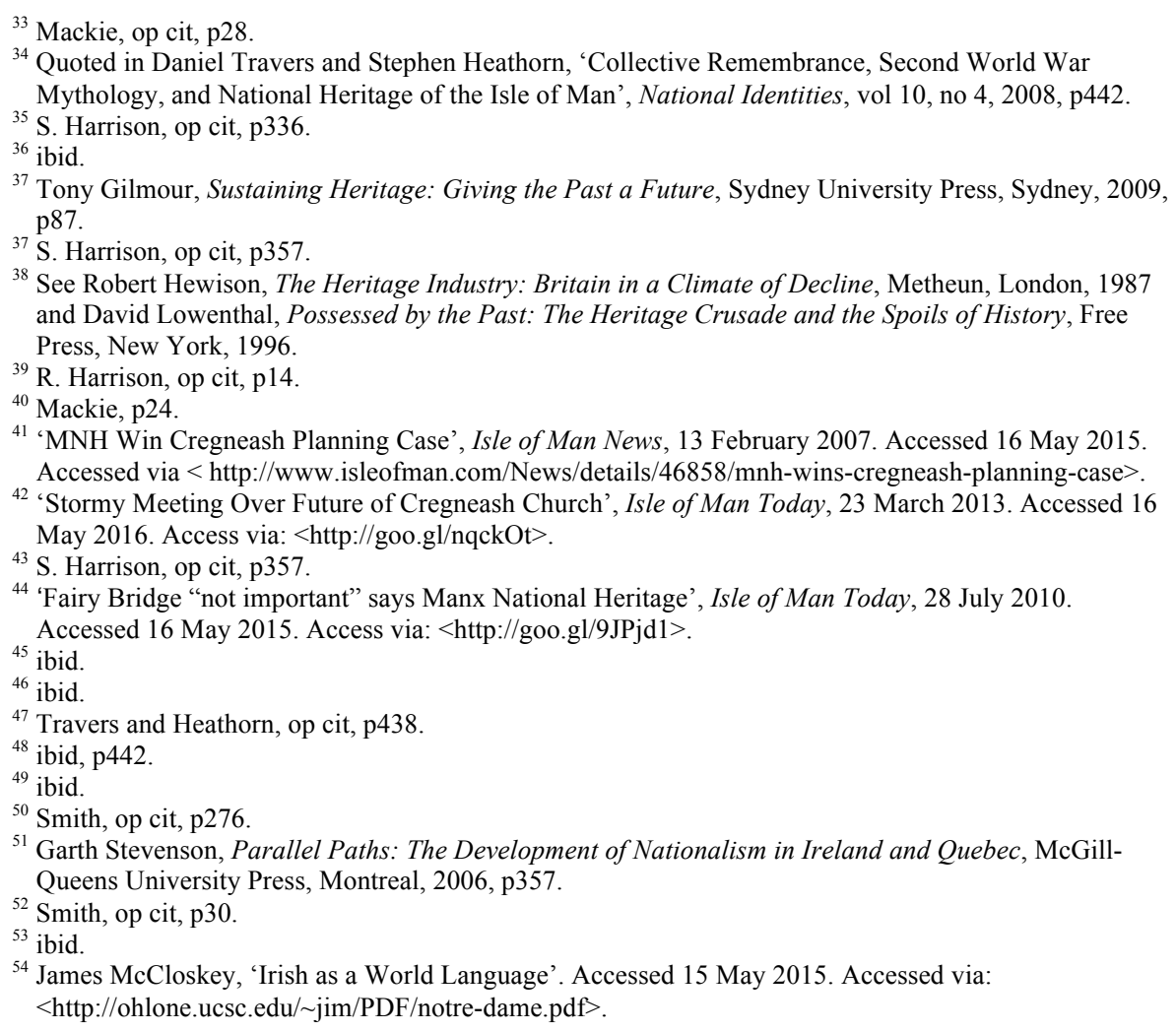

